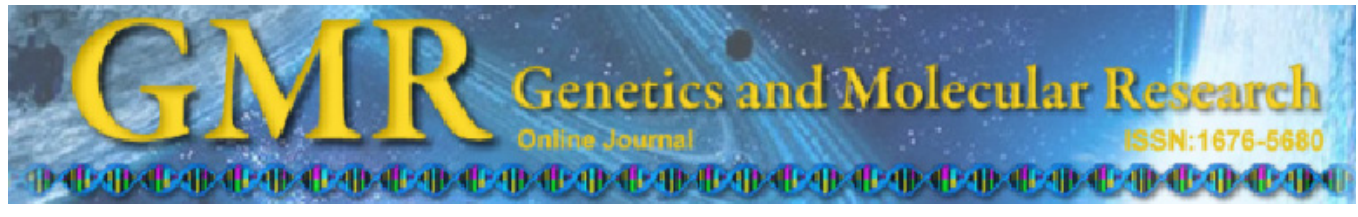

\title{
Cytoplasmic and extracellular expression of pharmaceutical-grade mycobacterial 65-kDa heat shock protein in Lactococcus lactis
}

\author{
M.S.P. de Azevedo ${ }^{1}$, C.S. Rocha ${ }^{1}$, N. Electo ${ }^{1}$, D.S. Pontes ${ }^{1}$, J.B. Molfetta ${ }^{2}$, \\ E.D.C. Gonçalves ${ }^{2}$, V. Azevedo ${ }^{1}$, C.L. Silva ${ }^{2,3}$ and A. Miyoshi ${ }^{1}$ \\ ${ }^{1}$ Departamento de Biologia Geral, Instituto de Ciências Biológicas, \\ Universidade Federal de Minas Gerais, Belo Horizonte, MG, Brasil \\ ${ }^{2}$ Farmacore Biotecnologia Ltda., Ribeirão Preto, SP, Brasil \\ ${ }^{3}$ Departamento de Bioquímica e Imunologia, \\ Escola de Medicina de Ribeirão Preto, Universidade de São Paulo, \\ Ribeirão Preto, SP, Brasil \\ Corresponding author: A. Miyoshi / V. Azevedo \\ E-mail: miyoshi@icb.ufmg.br/vascoariston@gmail.com
}

Genet. Mol. Res. 11 (2): 1146-1157 (2012)

Received November 12, 2012

Accepted April 13, 2012

Published April 27, 2012

DOI http://dx.doi.org/10.4238/2012.April.27.14

\begin{abstract}
Lactic acid bacteria (LAB) are an attractive and safe alternative for the expression of heterologous proteins, as they are nonpathogenic and endotoxin-free organisms. Lactococcus lactis, the LAB model organism, has been extensively employed in the biotechnology field for large-scale production of heterologous proteins, and its use as a "cell factory" has been widely studied. We have been particularly interested in the use of $L$. lactis for production of heat shock proteins (HSPs), which reportedly play important roles in the initiation of innate and adaptive immune responses. However, this activity has been questioned, as LPS contamination appears to be responsible for most, if not all, immunostimulatory activity of HSPs. In order to study the effect of pure HSPs on the immune system, we constructed recombinant $L$. lactis strains able to produce and properly address the Mycobacterium leprae 65-kDa HSP (Hsp65) to the cytoplasm or to the extracellular medium, using a xylose-induced expression system.
\end{abstract}


Approximately $7 \mathrm{mg} / \mathrm{L}$ recombinant Hsp65 was secreted. Degradation products related to lactococcal HtrA activity were not observed, and the Limulus amebocyte lysate assay demonstrated that the amount of LPS in the recombinant Hsp65 preparations was 10-100 times lower than the permitted levels established by the U.S. Food and Drug Administration. These new L. lactis strains will allow investigation of the effects of $M$. leprae Hsp65 without the interference of LPS; consequently, they have potential for a variety of biotechnological, medical and therapeutic applications.

Key words: Heat shock proteins; LPS-free Hsp65; Lactococcus lactis; Mycobacterium leprae

\section{INTRODUCTION}

Over the last 30 years, there have been considerable advances in technology for producing recombinant proteins in bacterial expression systems. The use of bacteria to produce recombinant proteins is very attractive because they are genetically well-characterized and because they are easy to culture on inexpensive substrates (Brondyk, 2009). Escherichia coli was the first bacterial host used to produce recombinant proteins and remains one of the most widely used bacteria for the expression of heterologous proteins. The advantage of E. coli consists in its ability to produce proteins in large quantities and to grow very quickly. However, despite these useful characteristics, it also has some drawbacks (Terpe, 2006; Demain and Vaishnav, 2009). The main problem associated with the use of E. coli is the accumulation of endotoxins (referred to as lipopolysaccharides - LPS). LPS are large molecules found in the outer membrane of Gram-negative bacterial cell walls that can bind to many kinds of receptors, resulting in the activation of various types of intracellular signaling pathways and production of proinflammatory cytokines. Consequently, LPS acts as a powerful activator of innate immune responses and is responsible for endotoxic shock (Cardoso et al., 2007; Bryant et al., 2010). Moreover, this bacterium cannot express very large proteins and high expression of recombinant protein often leads to the accumulation of inactive protein aggregates (inclusion bodies) (Brondyk, 2009).

To overcome these limitations, lactic acid bacteria (LAB) have emerged as an attractive and safe alternative, not only due to their "GRAS" (Generally Regarded As Safe) status granted by the U.S. Food and Drug Administration (FDA), but also because they are noninvasive, nonpathogenic, endotoxin-free and do not form inclusion bodies (Wells and Mercenier, 2008). Lactococcus lactis, the LAB model, has been widely used for large-scale production of heterologous proteins for the last two decades (Mierau and Kleerebezem, 2005). Its metabolism is relatively simple and well-known, and laboratory strains do not produce the extracytoplasmic protease PrtP. Furthermore, there are several genetic tools available for the production of heterologous proteins in L. lactis (Morello et al., 2008). Its genetic accessibility has allowed a variety of new applications to be developed, beyond its traditional use in food fermentation. For example L. lactis has been genetically engineered to produce cytokines (Marinho et al., 2010), enzymes (Du et al., 2010), membrane proteins (Frelet-Barrand et al., 2010), and bacterial and viral antigens, expressed either intra- or extracellularly (Van Huynegem et al., 2009). 
Therefore, its use as a "cell factory" has been extensively studied.

We have been particularly interested in the use of L. lactis as a factory for the production of heat shock proteins (HSPs), which is a group of molecular chaperones that are highly conserved across species. Their expression is induced by a wide variety of stresses (including high temperature, anoxia, and ethanol) (Lindquist and Craig, 1988). Under stress conditions, HSPs promote selective degradation of misfolded proteins and they prevent protein aggregation by facilitating their correct conformation (Rajaiah and Moudgil, 2009). These proteins have also been reported to play important roles in the initiation of innate as well as adaptive immune responses by activating antigen-presenting cells, such as dendritic cells and macrophages (Tsan and Gao, 2009). However, the immunostimulatory activity of HSPs has been questioned. Molecules such as LPS and other endotoxins have the same effect on the immune system (Osterloh et al., 2007). Gao and Tsan (2003) demonstrated that the reported proinflammatory cytokine-inducing effect of 60- and 70-kDa HSP (Hsp60 and Hsp70) is due to contamination with LPS and LPS-associated molecules. These contaminants appear to be responsible for most, if not all, of the reported in vitro capacity to induce intracellular signalling, as highly purified HSPs did not alter cell function, such as upregulation and/or downregulation of genes that control cytokine production (Tsan and Gao, 2009).

To be able to study how pure HSPs affect the immune system, we constructed recombinant L. lactis strains secreting Mycobacterium leprae 65-kDa HSP (Hsp65), using a xyloseinducible expression system (XIES) (Miyoshi et al., 2004). This protein is reported to be an immunodominant antigen eliciting both humoral and cellular responses. Immunization with DNA-hsp65 produced prophylactic and therapeutic effects in a murine model of tuberculosis (Silva, 1999). This protein also induced the reduction of established tumors in mouse models (Victora et al., 2009), and it is protective against experimentally induced arthritis in mice (Santos-Junior et al., 2005). These L. lactis strains offer the significant advantage of producing recombinant Hsp65 that is endotoxin-free, which could be used for biotechnological and therapeutic applications.

\section{MATERIAL AND METHODS}

\section{Bacterial strains, plasmids and growth conditions}

Bacterial strains and plasmids used in this study are listed in Table 1. The L. lactis NCD02118 strains were grown in Difco M17 broth, supplemented with 0.5\% glucose (GM17) or $1 \%$ xylose (XM17), at $30^{\circ} \mathrm{C}$, without agitation. When required, $10 \mu \mathrm{g} / \mathrm{mL}$ chloramphenicol was added to the medium. The E. coli strains were aerobically grown at $37^{\circ} \mathrm{C}$ in Luria-Bertani medium containing $100 \mu \mathrm{g} / \mathrm{mL}$ ampicillin or $10 \mu \mathrm{g} / \mathrm{mL}$ chloramphenicol, when needed.

\section{DNA manipulation}

The procedures for DNA manipulation were carried out as described by Sambrook et al. (1989), with a few modifications. The plasmids were purified by the alkaline lysis method, and the quality of the products that were obtained, including their concentration and purity, was determined by measuring absorbance at 260 and $280 \mathrm{~nm}$ in a spectrophotometer (BioPhotometer plus Eppendorf). Restriction and modification endonucleases, as well as ligation reactions, were used and run according to recommendations of the supplier (Invitrogen). 
Expression of mycobacterial Hsp65 in Lactococcus lactis

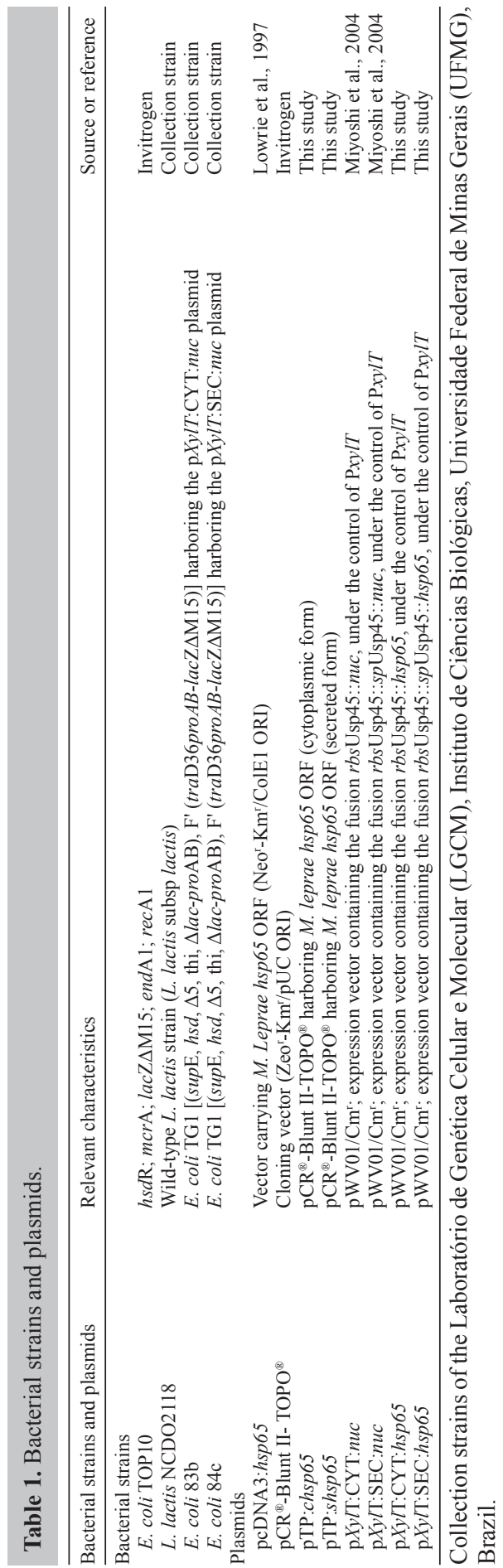




\section{Cloning and expression of recombinant M. leprae Hsp65 in E. coli and L. lactis}

To construct L. lactis strains producing either cytoplasmic (CYT) or secreted (SEC) forms of the M. leprae Hsp65 antigen, the hsp65 ORF was PCR-amplified from the pcDNA3:hsp65 plasmid (Table 1). The primers that were used, which contained an artificial restriction site at both extremities, were based on the genomic DNA sequence of $M$. leprae TN (GenBank Accession No. M14341). These primers are listed in Table 2. Subsequently, the amplicons corresponding to the CYT and SEC forms of the antigen were cloned into the $\mathrm{pCR}^{\circledR}$-Blunt II-TOPO ${ }^{\circledR}$ in E. coli TOP10 to generate the intermediate plasmids: pTP:chsp65 and pTP:shsp65. These plasmids were later digested with the restriction endonucleases NsiI and EcoRI, allowing the release of the ORFs "CYThsp65" and "SEChsp65". These fragments were purified and cloned into " $\mathrm{p} X y l \mathrm{~T}: \mathrm{CYT}$ " and "p $X y l \mathrm{~T}: \mathrm{SEC}$ " backbones, respectively, which were purified from $N s i \mathrm{I} / E c o$ RI cut of $\mathrm{p} X y l \mathrm{~T}: \mathrm{CYT}: n u c$ and $\mathrm{p} X y l \mathrm{~T}: \mathrm{SEC}: n u c$. The final plasmids, $\mathrm{p} X y l \mathrm{~T}: \mathrm{CYT}: h s p 65$ and $\mathrm{p} X y l \mathrm{~T}: \mathrm{SEC}: h s p 65$ (Figure 1), were first obtained in E. coli and then transferred to L. lactis NCDO2118 by electroporation. The presence of the expression vectors with the inserts was confirmed by PCR and DNA sequencing.
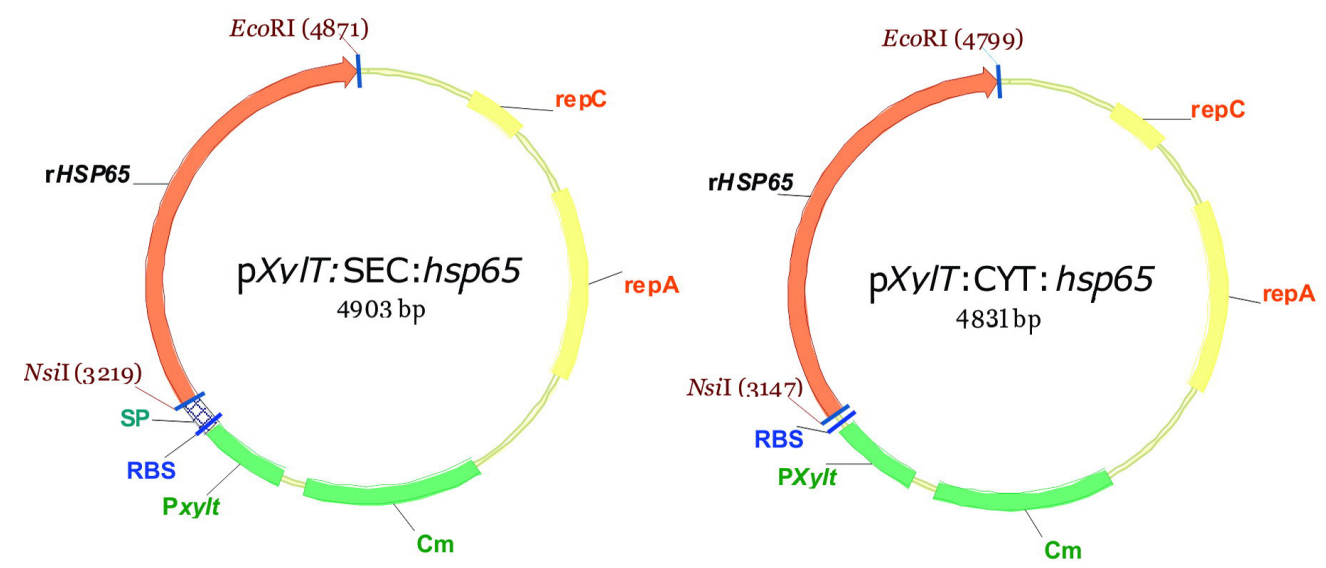

Figure 1. Schematic representation of the xylose-inducible expression vectors for intracellular or extracellular production of rHsp65. For details of plasmid construction, see the text. PxylT = xylose-inducible promoter; RBSUsp45 = ribosome binding site of Usp45; rHsp65 = recombinant Mycobacterium leprae hsp65 coding sequence; $\mathrm{Cm}=$ chloramphenicol resistance; $\mathrm{SP}=$ signal peptide; repA and repC $=$ replication origin; $E c o \mathrm{RI}$ and $N s i \mathrm{I}=$ restriction enzymes.

\section{Conditions of xylose induction}

On the first day, a single colony of wild-type or recombinant L. lactis NCDO2118 (harboring $\mathrm{p} X y l \mathrm{~T}: \mathrm{CYT}: h s p 65$ or $\mathrm{p} X y l \mathrm{~T}: \mathrm{SEC}: h s p 65$ ) was grown at $30^{\circ} \mathrm{C}$, without agitation, in $5 \mathrm{~mL}$ GM17, containing $10 \mu \mathrm{g} / \mathrm{mL}$ chloramphenicol, when needed. On the second day, the overnight culture was diluted 1:10,000 in $10 \mathrm{~mL}$ fresh XM17, supplemented with $10 \mu \mathrm{g} /$ $\mathrm{mL}$ chloramphenicol, when required, to induce the expression of the hsp 65 ORF. On the third day, when a 2.0 optical density at $600 \mathrm{~nm}\left(\mathrm{OD}_{600 \mathrm{~mm}}\right)$ was reached, protein was extracted and analyzed by Western blotting. 


\section{Protein extractions}

Protein sample preparation from L. lactis cultures was performed as previously described (Le Loir et al., 1998), with some modifications. Samples were prepared from $2 \mathrm{~mL}$ both induced and noninduced cultures. Next, they were centrifuged for $10 \mathrm{~min}$ at $4{ }^{\circ} \mathrm{C}$, at $12,000 \mathrm{~g}$. Later, the supernatant and the pellet were treated separately. The supernatant was run through a $0.2-\mu \mathrm{m}$ pore-size filter and $100 \mu \mathrm{L} 100 \%$ trichloroacetic acid was then added for protein precipitation. Dithiothreitol (DTT; $10 \mathrm{mM}$ ) and $1 \mathrm{mM}$ phenylmethylsulfonyl fluoride (PMSF) were also added to the filtrate. This was then incubated for $1 \mathrm{~h}$ on ice and centrifuged $\left(20 \mathrm{~min}, 12,000 \mathrm{~g}, 4^{\circ} \mathrm{C}\right)$. The pellet was resuspended in $50 \mathrm{mM} \mathrm{NaOH}$. The original cell pellet was resuspended in $100 \mu \mathrm{L}$ TES-Lys buffer (25\% sucrose, $1 \mathrm{mM}$ EDTA, $50 \mathrm{mM}$ Tris-HCl, $\mathrm{pH} 8.0,10 \mathrm{mg} / \mathrm{mL}$ lysozyme), $1 \mathrm{mM}$ PMSF and $10 \mathrm{mM}$ DTT. Afterwards, samples were incubated at $37^{\circ} \mathrm{C}$ for $30 \mathrm{~min}$ and $50 \mu \mathrm{L} 20 \% \mathrm{SDS}$ was then added to the lysate.

\section{Protein quantification and Western blot analyses}

The Bradford method (Bradford, 1976) was used to determine the concentration of total proteins extracted from L. lactis. Sodium dodecyl sulfate-polyacrylamide gel electrophoresis (SDS-PAGE) was performed as described by Laemmli (1970). Western blotting analyses were conducted according to Sambrook et al. (1989), using anti-Hsp65 antibodies (1:2500) (Farmacore Biotecnologia Ltda.) and rabbit anti immunoglobulin (IgG), conjugated to alkaline phosphatase (Sigma). The immunodetection blots were scanned and the intensity of the Hsp65 signals was compared to that of the positive control used, which was a known amount of a purified Hsp65 produced in E. coli (Farmacore Biotecnologia Ltda.).

\section{Endotoxin analysis}

The Limulus amebocyte lysate (LAL) test was conducted to check the endotoxin-free condition of the wild and recombinant strains of L. lactis, as recommended by European and US Pharmacopeias, using the QCL 1000-LAL test kit (Lonza). Briefly, proteins were extracted from L. lactis and endotoxin concentrations in the samples were calculated based on a standard curve, which ranged from 0.025 to 50 endotoxin units $(\mathrm{EU}) / \mathrm{mL}$. The absorbance in each well was measured at $405 \mathrm{~nm}$.

\section{RESULTS AND DISCUSSION}

\section{Construction of recombinant $L$. lactis strains to produce either cytoplasmic or secreted forms of Hsp65 antigen}

We produced, for the first time, both cytoplasmic and secreted forms of M. leprae Hsp65 in L. lactis strain NCDO2118 using XIES. The choice of XIES was based on some advantageous features compared to other expression systems, such as its ability to be switched on or off by simply adding either xylose or glucose, respectively (Miyoshi et al., 2004). It is less expensive and more secure for laboratory use compared to the other available methods. 
As described in Material and Methods, two expression vectors were initially constructed, $\mathrm{p} X y l \mathrm{~T}: \mathrm{CYT}: h s p 65$ (cytoplasmic Hsp65 production) and $\mathrm{p} X y l \mathrm{~T}: \mathrm{SEC}: h s p 65$ (secreted Hsp65 production). These plasmids are derived from two broad-host-range expression vectors, pCYT:Nuc and pSEC:Nuc (Bermudez-Humaran et al., 2003). The former contains i) the PxylT promoter (Jamet, 2001), ii) the ribosome-binding site of the lactococcal usp 45 gene (van Asseldonk et al., 1990), and iii) the DNA fragment encoding the mature part of the staphylococcal nuclease, NucB (Le Loir et al., 1994). The latter contains all of this DNA sequence, plus the signal peptide of the Usp45 coding sequence ( $s p U s p 45)$, necessary for the secretion of NucB.

The vector to target the Hsp65 protein to the cytoplasm of L. lactis ( $\mathrm{p} X y / \mathrm{T}: \mathrm{CYT}:$ hsp65) was obtained as follows: A 1626-bp DNA fragment encoding Hsp65 was PCR-amplified from the plasmid pcDNA3:hsp65. Primers were designed using the GenBank nucleotide database of the M. leprae TN hsp65 gene (GenBank accession No. M14341). Artificial restriction sites (NsiI and EcoRI) and extra bases were introduced into the primers to clone the hsp65 ORF in-frame into the expression vector $\mathrm{p} X y l \mathrm{~T}: \mathrm{CYT}: n u c$ (Table 2). The amplicon generated was treated with the enzymes $N s i$ and $E c o$ RI prior to cloning into purified backbone isolated from $N s i \mathrm{I}-E c o$ RI-cut $\mathrm{pCR}^{\circledR}$ Blunt II-TOPO ${ }^{\circledR}$ cloning vector. The construction of this intermediate plasmid (pTP:chsp65) was important because treatment with restriction enzymes releases inserts with cohesive extremities; this allowed correct cloning into the $L$. lactis plasmid $\mathrm{p} X y l \mathrm{~T}: \mathrm{CYT}: n u c$. The vector $\mathrm{pTP}:$ chsp 65 was transformed in E. coli TOP 10 and then recovered to confirm the presence of hsp 65 by PCR analysis. Later, pTP:chsp65 was digested with $N s i$ I and $E c o$ RI, and the released fragment was cloned into the purified backbone isolated from $N$ siI-EcoRI-cut $\mathrm{p} X y l \mathrm{~T}$ :CYT:nuc, replacing the DNA sequence encoding NucB. The vector to direct Hsp65 to the extracellular medium, $\mathrm{p} X y l \mathrm{~T}$ :SEC:hsp65, was obtained using the same procedures. First, the hsp 65 ORF was PCR-amplified from pcDNA3:hsp65. The oligonucleotides again contained artificial restriction sites for NsiI and $E c o R I$, along with extra bases, which were added to adapt the reading frame of the $s p \mathrm{Usp} 45$ coding sequence (Table 2). The PCR product was digested with NsiI and EcoRI and then subcloned into the $\mathrm{pCR}^{\circledR}$ Blunt II-TOPO ${ }^{\circledR}$ vector, previously cut with the same restriction enzymes. Subsequently, the intermediate plasmid, pTP:shsp65, was introduced into E. coli TOP 10 by electroporation and then recovered to check for the $h s p 65$ ORF by PCR analysis. Subsequently, pTP:shsp65 was cut with $N s i$ and EcoRI, and the shsp 65 fragment, containing cohesive extremities, was cloned into purified backbone isolated from NsiI-EcoRI-cut pSEC:Nuc. The final plasmids, $\mathrm{p} X y l \mathrm{~T}: \mathrm{CYT}: h s p 65$ or $\mathrm{p} X y l \mathrm{~T}: \mathrm{SEC}: h s p 65$ (Figure 1), were successfully transformed in both E. coli TOP10 and L. lactis NCDO2118. All constructs were confirmed by PCR and DNA sequencing analysis.

Table 2. Primers used for the polymerase chain reactions.

\begin{tabular}{ll}
\hline Primer & Sequence \\
\hline SCFhsp65 (coding strand for the SEC form) & 5'-CCATGCATCAGCCAAGACAATTGCGTACG-3' \\
CTFhsp65 (coding strand for the CYT form) & 5'-CCATGCATGCCAAGACAATTGCGTACG-3' \\
SCTRhsp65 (complementary strand for the CYT and SEC form) & 5'-CC GAATTCTCAGAAGTCCATACCACCC-3' \\
\hline
\end{tabular}

The $N s i$ site is underlined and the $E c o$ RI site is underlined and in bold. $\boldsymbol{A}$ (in the first line) was added to adapt the reading frame of $s p \mathrm{Usp} 45$. 


\section{L. lactis is able to produce and secrete LPS-free M. leprae Hsp65}

Western blot experiments of xylose-induced and noninduced cultures were conducted to detect the production of Hsp65 in L. lactis carrying the plasmid $\mathrm{p} X y l \mathrm{~T}: \mathrm{CYT}: h s p 65$ or $\mathrm{p} X y l \mathrm{~T}$ :SEC:hsp65, allowing us to characterize the strains. Analysis of induced stationaryphase cell lysates and culture supernatants demonstrated that both L. lactis (pXylT:CYT:hsp65) (hereafter called CYT:hsp65) and L. lactis (pXylT:SEC:hsp65) (hereafter called SEC:hsp65) were able to produce and properly direct the recombinant protein. No signal of the antigen was detected in the noninduced cultures (Figures 2 and 3). Analysis of protein content showed that the band migrated at the expected position $(65 \mathrm{kDa})$, which is the size of M. leprae Hsp65. The immunoblotting assay also revealed that this protein was expressed without signs of degradation, since only one band was detected (Figure 2). Usually, a large number of heterologous proteins produced in wild-type L. lactis are degraded by the major extracellular protease, HtrA (Poquet et al., 2000). Absence of degradation by this protease can be explained by the fact that HSPs are among the most highly conserved proteins, which is evident from its conserved DNA and protein sequences (Silva, 1999). This lack of degradation products suggests that $L$. lactis does not recognize this antigen as an exogenous protein. Recombinant Hsp65 (rHsp65) produced by induced L. lactis strain CYT:hsp65 was retained in the cytoplasm, as expected, since this strain harbors a vector that lacks the $s p$ Usp 45 coding sequence (lanes CYT:hsp65, Figure 2). We also found that induced L. lactis strain SEC: $h s p 65$ secreted large amounts of this antigen. We found that approximately $7 \mathrm{mg} / \mathrm{L} \mathrm{rHsp} 65$ were exported to the extracellular medium. Moreover, the secretion efficiency (ratio of mature protein secreted in the supernatant as a fraction of intracellular content of this protein) was estimated to be $50 \%$ (Figure 3). Accumulation of rHsp65 within the cytoplasm can be attributed to intrinsic allosteric properties of HSPs (Sigler et al., 1998). This protein can bind to polypeptides and alter their conformations; consequently, it remains in the cytoplasm and cannot be exported by the L. lactis secretion machinery. Few studies have reported the production of recombinant proteins in different cellular locations (i.e., cytoplasm, cell wall or extracellular medium) under the same induction conditions and using the same promoter (Le Loir et al., 2005). We demonstrated that rHsp65 is efficiently produced in both the cytoplasm and secreted forms to the extracellular medium, confirming the ability of XIES to produce and correctly target recombinant proteins.

To determine if this antigen was produced without any traces of LPS, the quantity of endotoxin in bacterially expressed Hsp65 preparations was evaluated using the chromogenic LAL test (Table 3). The samples contained less LPS than the limit set by the FDA, as expected, since L. lactis is a Gram-positive bacterium and since this endotoxin occurs as part of the cell structure of Gram-negative bacteria (Cardoso et al., 2007). The FDA currently requires the LAL test to be performed on all bacterial, human and animal products intended to be used for medical proposes. The LPS levels that we found varied from $0.00137-0.01119 \mathrm{ng} / \mu \mathrm{g}$ protein, approximately 10-100 times lower than the levels established by the FDA, which stipulates that commercial preparations of recombinant proteins must contain less than $1 \mathrm{EU}$ or $0.1 \mathrm{ng}$ LPS/ $\mu \mathrm{g}$ protein. According to Salek-Ardakani et al. (2002), it is crucial to eliminate or at least significantly reduce LPS levels because sub-nanogram quantities can alter the phenotype of various cell types, induce complement activation, and cause production of proinflammatory cytokines and reactive oxygen species, both in vitro and in vivo. These effects can complicate studies of the biological effect of proteins, constituting a serious problem for research on such 
proteins. For instance, there have been concerns that the reported cytokine-inducing effects of HSPs may be a result of something other than the HSPs; they could be due to substances bound to HSPs or present as contaminants, such as LPS and lipoproteins (Majde, 1993). Using highly purified HSP preparations, a series of papers have demonstrated that the HSP cytokine functions are in fact a result of contaminating bacterial products (for example lipoproteins, flagellins and mainly LPS) (Tsan and Gao, 2009). Moreover, although several purification protocols have been developed and can reduce the endotoxin content below the threshold level, an absolute guarantee cannot be given. A part of the final product may become accidentally contaminated and fail quality control assays, increasing the cost of the final product. Despite the development of novel methods designed to remove endotoxins from biological samples, more research is needed in this field (Magalhaes et al., 2007). For these reasons, L. lactis is an attractive alternative compared to other expression systems, especially E. coli, since it is capable of naturally producing LPS-free recombinant proteins.

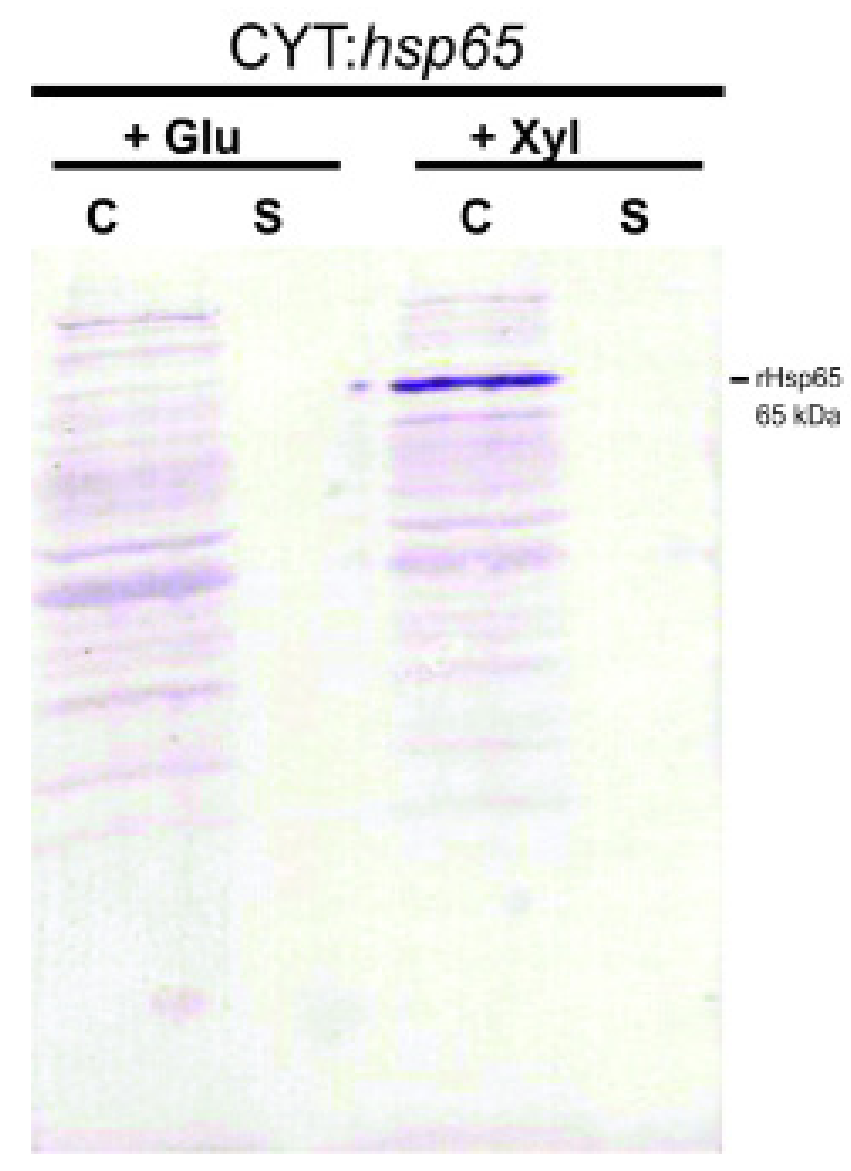

Figure 2. Cytoplasmic rHsp65 production. Protein extracts of noninduced (Glu lanes) and xylose-induced (Xyl lanes) culture samples of Lactococcus lactis NCDO2118 (CYT:hsp65) strain in stationary-phase $\left(\mathrm{OD}_{600}=2.0\right)$ were prepared from cell (C lanes) and supernatant (S lanes) fractions and were analyzed by Western blotting using anti-Hsp65 antibodies. 


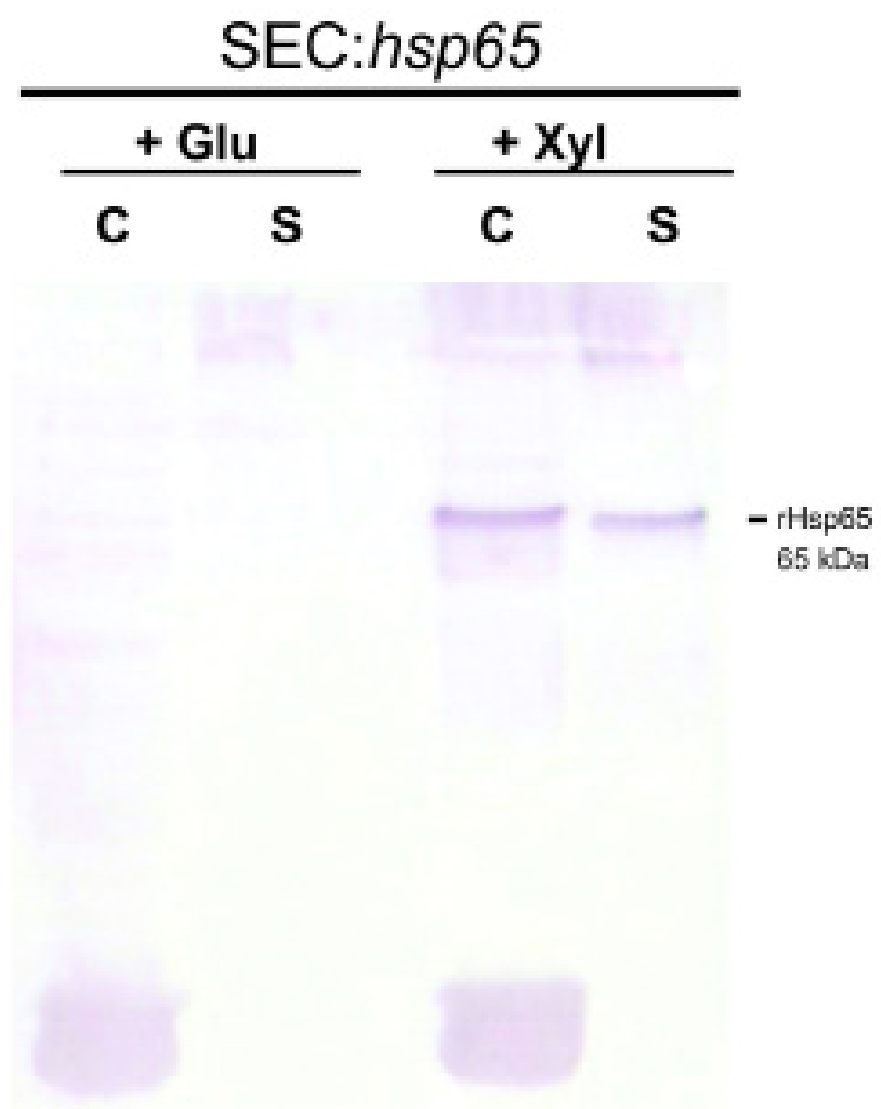

Figure 3. Extracellular rHsp65 production. Protein extracts of noninduced (Glu lanes) and xylose-induced (Xyl lanes) culture samples of Lactococcus lactis NCDO2118 (SEC:hsp65) strain in stationary-phase $\left(\mathrm{OD}_{600}=2.0\right)$ were prepared from cell (C lanes) and supernatant (S lanes) fractions and were analyzed by Western blotting using anti-Hsp65 antibodies.

\section{Table 3. Primers used for the polymerase chain reactions.}

\begin{tabular}{|c|c|c|c|}
\hline Lactococcus lactis strain & Accepted value in EU/ $\mu \mathrm{g}$ & Mean EU/ $\mu \mathrm{g}$ obtained & Final \\
\hline CYT:hsp65 C I & $<0.1$ & 0.00881 & A \\
\hline CYT:hsp65 C NI & $<0.1$ & 0.00501 & A \\
\hline CYT:hsp65 S I & $<0.1$ & 0.00458 & A \\
\hline CYT:hsp65 S NI & $<0.1$ & 0.00641 & A \\
\hline SEC:hsp65 C I & $<0.1$ & 0.00192 & A \\
\hline SEC:hsp65 C NI & $<0.1$ & 0.00542 & A \\
\hline SEC:hsp65 S I & $<0.1$ & 0.00137 & A \\
\hline SEC:hsp65 S NI & $<0.1$ & 0.00205 & A \\
\hline Wild-type strain NCDO2118 C & $<0.1$ & 0.01119 & A \\
\hline Wild-type strain NCDO2118 S & $<0.1$ & 0.00225 & A \\
\hline
\end{tabular}

$\mathrm{A}=$ approved; $\mathrm{C}=$ cellular fraction; $\mathrm{S}=$ secreted fraction; $\mathrm{I}=$ xylose-induced $L$. lactis culture; $\mathrm{NI}=$ noninduced L. lactis culture; EU/ $\mu \mathrm{g}$ (endotoxin units $/ \mu \mathrm{g}$ ) $=0.1 \mathrm{ng} \mathrm{LPS} / \mu \mathrm{g}$ protein; CYT: $h s p 65=L$. lactis producing the cytoplasmic form of Hsp65; SEC:hsp65 = L. lactis producing the secreted form of Hsp65. 


\section{CONCLUSIONS}

In conclusion, we engineered recombinant $L$. lactis strains able to produce and target the M. leprae Hsp65 to the cytoplasm or to the extracellular medium. Degradation products, related to lactococcal HtrA activity, and LPS contamination were not observed in any fraction from induced L. lactis culture samples (CYT:hsp65 and SEC:hsp65). Thus, these strains seem to be able to produce and deliver (cytoplasm or extracellular medium) a stable and LPS-free form of Hsp65. This alternative expression strategy can open up a wide range of pharmaceutical and medical applications for this antigen.

\section{ACKNOWLEDGMENTS}

Research supported by Farmacore Biotecnologia Ltda., Fundação de Amparo à Pesquisa do Estado de São Paulo (FAPESP) and Conselho Nacional de Desenvolvimento Científico e Tecnológico (CNPq).

\section{REFERENCES}

Bermudez-Humaran LG, Langella P, Commissaire J, Gilbert S, et al. (2003). Controlled intra- or extracellular production of staphylococcal nuclease and ovine omega interferon in Lactococcus lactis. FEMS Microbiol. Lett. 224: 307-313.

Bradford MM (1976). A rapid and sensitive method for the quantitation of microgram quantities of protein utilizing the principle of protein-dye binding. Anal. Biochem. 72: 248-254.

Brondyk WH (2009). Selecting an appropriate method for expressing a recombinant protein. Methods Enzymol. 463: 131-147.

Bryant CE, Spring DR, Gangloff M and Gay NJ (2010). The molecular basis of the host response to lipopolysaccharide. Nat. Rev. Microbiol. 8: 8-14.

Cardoso LS, Araujo MI, Goes AM, Pacifico LG, et al. (2007). Polymyxin B as inhibitor of LPS contamination of Schistosoma mansoni recombinant proteins in human cytokine analysis. Microb. Cell Fact. 6: 1.

Demain AL and Vaishnav P (2009). Production of recombinant proteins by microbes and higher organisms. Biotechnol. Adv. 27: 297-306.

Du Y, Gisselberg JE, Johnson JD, Lee PJ, et al. (2010). Lactococcus lactis fabH, encoding beta-ketoacyl-acyl carrier protein synthase, can be functionally replaced by the Plasmodium falciparum congener. Appl. Environ. Microbiol. 76: 3959-3966.

Frelet-Barrand A, Boutigny S, Kunji ER and Rolland N (2010). Membrane protein expression in Lactococcus lactis. Methods Mol. Biol. 601: 67-85.

Gao B and Tsan MF (2003). Endotoxin contamination in recombinant human heat shock protein 70 (Hsp70) preparation is responsible for the induction of tumor necrosis factor alpha release by murine macrophages. J. Biol. Chem. 278: $174-179$.

Jamet E (2001). Etude de L'expression et de la Régulation des Gènes Impliqués Dans le Métabolisme Carboné Chez Lactococcus lactis. Institut National Agronomique de Paris-Grignon, Paris.

Laemmli UK (1970). Cleavage of structural proteins during the assembly of the head of bacteriophage T4. Nature 227: 680-685.

Le Loir Y, Gruss A, Ehrlich SD and Langella P (1994). Direct screening of recombinants in gram-positive bacteria using the secreted staphylococcal nuclease as a reporter. J. Bacteriol. 176: 5135-5139.

Le Loir Y, Gruss A, Ehrlich SD and Langella P (1998). A nine-residue synthetic propeptide enhances secretion efficiency of heterologous proteins in Lactococcus lactis. J. Bacteriol. 180: 1895-1903.

Le Loir Y, Azevedo V, Oliveira SC, Freitas DA, et al. (2005). Protein secretion in Lactococcus lactis: an efficient way to increase the overall heterologous protein production. Microb. Cell Fact. 4: 2.

Lindquist S and Craig EA (1988). The heat-shock proteins. Annu. Rev. Genet. 22: 631-677.

Lowrie DB, Silva CL, Colston MJ, Ragno S, et al. (1997). Protection against tuberculosis by a plasmid DNA vaccine. Vaccine 15: 834-838. 
Magalhaes PO, Lopes AM, Mazzola PG, Rangel-Yagui C, et al. (2007). Methods of endotoxin removal from biological preparations: a review. J. Pharm. Pharm. Sci. 10: 388-404.

Majde JA (1993). Microbial cell-wall contaminants in peptides: a potential source of physiological artifacts. Peptides 14: 629-632.

Marinho FA, Pacifico LG, Miyoshi A, Azevedo V, et al. (2010). An intranasal administration of Lactococcus lactis strains expressing recombinant interleukin-10 modulates acute allergic airway inflammation in a murine model. Clin. Exp. Allergy 40: 1541-1551.

Mierau I and Kleerebezem M (2005). 10 years of the nisin-controlled gene expression system (NICE) in Lactococcus lactis. Appl. Microbiol. Biotechnol. 68: 705-717.

Miyoshi A, Jamet E, Commissaire J, Renault P, et al. (2004). A xylose-inducible expression system for Lactococcus lactis. FEMS Microbiol. Lett. 239: 205-212.

Morello E, Bermudez-Humaran LG, Llull D, Sole V, et al. (2008). Lactococcus lactis, an efficient cell factory for recombinant protein production and secretion. J. Mol. Microbiol. Biotechnol. 14: 48-58.

Osterloh A, Kalinke U, Weiss S, Fleischer B, et al. (2007). Synergistic and differential modulation of immune responses by Hsp60 and lipopolysaccharide. J. Biol. Chem. 282: 4669-4680.

Poquet I, Saint V, Seznec E, Simoes N, et al. (2000). HtrA is the unique surface housekeeping protease in Lactococcus lactis and is required for natural protein processing. Mol. Microbiol. 35: 1042-1051.

Rajaiah R and Moudgil KD (2009). Heat-shock proteins can promote as well as regulate autoimmunity. Autoimmun. Rev. 8: 388-393.

Salek-Ardakani S, Stuart AD, Arrand JE, Lyons S, et al. (2002). High level expression and purification of the Epstein-Barr virus encoded cytokine viral interleukin 10: efficient removal of endotoxin. Cytokine 17: 1-13.

Sambrook J, Fritsch EF and Maniatis T (1989). Molecular Cloning: a Laboratory Manual. Cold Spring Harbor Laboratory, New York.

Santos-Junior RR, Sartori A, De Franco M, Filho Ribeiro OG, et al. (2005). Immunomodulation and protection induced by DNA-hsp65 vaccination in an animal model of arthritis. Hum. Gene Ther. 16: 1338-1345.

Sigler PB, Xu Z, Rye HS, Burston SG, et al. (1998). Structure and function in GroEL-mediated protein folding. Annu. Rev. Biochem. 67: 581-608.

Silva CL (1999). The potential use of heat-shock proteins to vaccinate against mycobacterial infections. Microbes. Infect. 1: 429-435.

Terpe K (2006). Overview of bacterial expression systems for heterologous protein production: from molecular and biochemical fundamentals to commercial systems. Appl. Microbiol. Biotechnol. 72: 211-222.

Tsan MF and Gao B (2009). Heat shock proteins and immune system. J. Leukoc. Biol. 85: 905-910.

van Asseldonk M, Rutten G, Oteman M, Siezen RJ, et al. (1990). Cloning of usp45, a gene encoding a secreted protein from Lactococcus lactis subsp. lactis MG1363. Gene 95: 155-160.

Van Huynegem K, Loos M and Steidler L (2009). Immunomodulation by genetically engineered lactic acid bacteria. Front Biosci. 14: 4825-4835.

Victora GD, Socorro-Silva A, Volsi EC, Abdallah K, et al. (2009). Immune response to vaccination with DNA-Hsp65 in a phase I clinical trial with head and neck cancer patients. Cancer Gene Ther. 16: 598-608.

Wells JM and Mercenier A (2008). Mucosal delivery of therapeutic and prophylactic molecules using lactic acid bacteria. Nat. Rev. Microbiol. 6: 349-362. 